\title{
Penanaman Karakter Siswa Sekolah Dasar Melalui Pembiasaan Harian dalam Perspektif Behaviorisme
}

\author{
Herlina Gantini $^{1}{ }^{\circledR}$ Endang Fauziati ${ }^{2}$
}

Universitas Muhammadiyah Surakarta, Indonesia

${ }^{\bowtie}$ E-mail: herlinag44@gmail.com

\begin{abstract}
Abstrak
Tujuan penelitian ini adalah untuk mengetahui program kegiatan pembiasaan harian dalam menanamkan karakter siswa SD Negeri 03 Bejen Karanganyar dipandang dari perspektif teori belajar behaviorisme. Menurut teori behaviorisme Albert Bandura, belajar adalah mengubah tingkah laku peserta didik melalui beberapa tahapan, yaitu tahap perhatian, tahap penyimpanan dalam ingatan, tahap reproduksi, dan tahap motivasi. Hal ini diwujudkan dalam sebuah pembiasaan harian. Metode penelitian yang digunakan adalah metode kualitatif deskriptif. Teknik pengumpulan data penelitian melalui observasi, wawancara, dan dokumentasi. Hasil dari penelitian ini menunjukkan bahwa program pembiasaan harian maupun mingguan baik yang terjadwal maupun kondisional yang dilaksanakan di SD Negeri 03 Bejen Karanganyar dapat membentuk sikap peserta didik yang berkarakter. Karakter yang terbentuk yaitu religius, disiplin, bertanggung jawab, toleransi, hormat dan santun, cinta tanah air, semangat kebangsaan, jujur, peduli lingkungan maupun sosial. Keberhasilan pembentukan karakter didukung sepenuhnya oleh lingkungan, proses pendidikan, dan para pengajar yang selalu menjadi contoh bagi peserta didik. Oleh karena itu tugas utama pengajar tidak hanya mengajarkan ilmu ( transfer of knowledge) tetapi juga mengajarkan nilai-nilai kehidupan (transfer of value).
\end{abstract}

Kata Kunci: Program Pembiasaan; Karakter; Behaviorisme.

\begin{abstract}
The purpose of this study was to determine the program of daily habituation activities in instilling the character of the students of SD Negeri 03 Bejen Karanganyar from the perspective of behaviorism learning theory. According to Albert Bandura's theory of behaviorism, learning is changing the behavior of students through several stages, namely the attention stage, the memory storage stage, the reproduction stage, and the motivation stage. This is manifested in a daily habit. The research method used is descriptive qualitative method. Research data collection techniques through observation, interviews, and documentation. The results of this study indicate that the daily and weekly habituation program, both scheduled and conditional, which is carried out at SD Negeri 03 Bejen Karanganyar can shape the character of students' attitudes. The characters formed are religious, disciplined, responsible, tolerant, respectful and polite, love the homeland, national spirit, honest, care about the environment and social. The success of character building is fully supported by the environment, the educational process, and the teachers who are always an example for students. Therefore, the main task of the teacher is not only to teach knowledge (transfer of knowledge) but also to teach the values of life (transfer of value).
\end{abstract}

Keywords: Habituation Program; Character; Behaviorism. 


\section{PENDAHULUAN}

Pada era globalisasi dimana arus informasi dan komunikasi semakin canggih, dunia seolah begitu sempit. Berbagai informasi dapat diperoleh dengan begitu mudah tanpa bisa dibuktikan kebenarannya dengan pasti. Globalisasi membawa pengaruh bagi bangsa Indonesia, baik itu positif maupun negatif. Negara timur, termasuk Indonesia yang menjunjung tinggi nilai adat dan budaya, tradisi serta spiritual keagamaan telah tergeser sedikit demi sedikit oleh budaya barat yang mengedepankan materialisme-sekuler. Hal itu merupakan ancaman bagi nilai-nilai karakter bangsa Indonesia. Ancaman globalisasi yang sedang dihadapi saat ini adalah semakin terkikisnya karakter peserta didik. Pembentukan karakter yang tepat dapat membentengi generasi muda dalam menghadapi era globalisasi.

"Karakter merupakan nilai - nilai perilaku manusia yang universal. Karakter sendiri identik dengan moral, akhlak, dan etika. Karakter manusia selalu berhubungan dengan Tuhan, dengan dirinya, dengan sesama manusia, maupun dengan lingkungannya. Karakter diwujudkan dalam pikiran, sikap, perasaan, perkataan, dan perbuatan berdasarkan norma-norma yang berlaku di masyarakat. Norma-norma tersebut meliputi norma agama, hukum, tata krama, budaya, dan adat istiadat" (Samrin, 2016).

Lembaga pendidikan mempunyai tugas yang sangat penting terkait dengan pendidikan moral dan karakter. Muhadjir Effendy (2016: p.iii) menyimpulkan bahwa "Bangsa besar adalah bangsa yang memiliki karakter kuat berdampingan dengan kompetensi yang tinggi, yang tumbuh dan berkembang dari pendidikan yang menyenangkan dan lingkungan yang menerapkan nilai-nilai baik dalam seluruh sendi kehidupan berbangsa dan bernegara." (Widyastuti, 2016).

Pendidikan adalah upaya menumbuhkembangan sumber daya manusia melalui proses dalam lingkungan masyarakat, dimulai dari pendidikan keluarga dan sekolah. Berdasarkan hal ini, bisa kita lihat bagaimana respon seorang siswa terhadap pelajaran di kelas maupun lingkungan sekolahnya yang sangat dipengaruhi oleh persepsinya terhadap guru pengajar dan teman-teman sekelasnya. Pendidikan baik formal maupun informal memiliki peran penting dalam mengembangkan psikososial siswa. "Perkembangan psikososial siswa dapat diartikan sebagai proses perkembangan kepribadian siswa dalam berhubungan dengan orang lain dalam posisinya sebagai anggota masyarakat" (Laila, 2015).

Zubaedi ( dalam Novia Elva, 2019: 3) menjelaskan bahwa "pendidikan karakter di Indonesia didasarkan pada sembilan pilar karakter dasar. Cinta kepada Allah dan semesta beserta isinya; tanggung jawab; disiplin dan mandiri; jujur, hormat dan santun; kasih sayang, peduli, dan kerja sama; percaya diri, kreatif, kerja keras, dan pantang menyerah; keadilan dan kepemimpinan; baik dan rendah hati; toleransi, cinta damai, dan persatuan adalah sembilan karakter dasar yang menjadi pilar tujuan pendidikan karakter."

Para ilmuwan barat juga mengakui pentingnya pendidikan moral dan karakter. Salah satunya adalah tokoh behaviorisme sekaligus kognitivisme yang terkenal dengan teori belajar sosial yaitu Albert Bandura. Bandura mengemukakan bahwa "proses perkembangan sosial dan moral siswa selalu berkaitan dengan proses belajar sebab prinsip dasar belajar hasil temuan Bandura ini adalah belajar sosial dan moral" (Muhibbin, 1995). Proses belajar inilah yang menentukan 
kemampuan siswa dalam bertingkah laku yang sesuai dengan norma yang berlaku di masyarakat.

Kajian terhadap pemikiran Bandura mengenai tahapan dalam pembentukan karakter pribadi anak memiliki kaitan yang erat antara teori belajar behavioristik dengan kognitif. Bandura memaparkan ada beberapa tahapan dalam proses pembentukan karakter pribadi anak. Tahap perhatian (attention), tahap penyimpanan dalam ingatan (retention), tahap reproduksi, tahap motivasi. Dalam tahap attention yang terlibat hanyalah proses behavioristik. Namun di dalam tahap penyimpanan, reproduksi, dan motivasi proses kognitif mulai terlibat di dalamnya disamping proses behavioristik.

Menurut teori behaviorisme, belajar adalah mengubah perilaku peserta didik dari tidak bisa menjadi bisa, dari tidak mengerti menjadi mengerti. Dan tugas pengajar adalah mengontrol stimulus dan lingkungan belajar agar perubahan mendekati tujuan yang diinginkan. Perubahan tingkah laku siswa akan terjadi apabila ada stimulus dan respon. Apa saja yang diberikan guru (stimulus) akan berpengaruh pada apa saja yang dihasilkan siswa (respon). Semakin sering stimulus diberikan, maka respon siswa akan semakin terlihat. Untuk itulah perlu diberikan pembiasaan sebagai wujud stimulus yang diberikan kepada siswa. Dengan dilakukan pembiasaan yang baik, diharapkan dapat terbentuk karakter siswa yang berkualitas.

Pembiasaan adalah kegiatan yang sengaja dilakukan secara berulang-ulang agar dapat menjadi sebuah kebiasaan. Inti dari pembiasaan adalah pengalaman. "Pembiasaan menempatkan manusia sebagai sesuatu yang istimewa, yang dapat menghemat kekuatan, karena akan menjadi kebiasaan yang melekat dan spontan, agar kekuatan itu dapat dipergunakan untuk berbagai kegiatan dalam setiap pekerjaan, dan aktivitas lainnya." (Mulyasa, 2013).

Sangat penting bagi orangtua maupun praktisi pendidikan untuk membentuk karakter anak sejak dini. Hal ini sesuai dengan hal yang dikatakan bahwa "Siapa yang membiasakan sesuatu di waktu mudanya, maka di waktu tua akan menjadi kebiasaannya." (Al-Abrasyi, 1974). Mengingat hal tersebut maka perlu dilakukan penelitian untuk mengetahui implikasi pembiasaan siswa disekolah untuk pembentukan karakter.

\section{METODE PENELITIAN}

Metode penelitian yang digunakan dalam penelitian ini adalah penelitian kualitatif. Metode kualitatif dilakukan pada saat kondisi terjadi secara alamiah (tanpa rekayasa), peneliti memiliki peran utama, teknik pengumpulan data dilakukan secara gabungan, analisis data bersifat induktif, hasil penelitiannya pun lebih menekankan pada makna daripada secara keseluruhan (Sugiyono, 2007).

Pendekatan yang digunakan adalah pendekatan kualitatif deskriptif. Jenis penelitian deskriptif kualitatif menggambarkan kondisi apa adanya, tanpa memberi perlakuan atau manipulasi pada variabel yang diteliti. Penelitian ini lebih menekankan makna pada hasilnya. Sumber data terdiri dari data primer dan data sekunder. Data primer diperoleh dari hasil wawancara dengan guru dan hasil observasi perilaku siswa SDN 03 Bejen Karanganyar. Sedangkan data sekunder diperoleh dari dokumentasi program pembiasaan secara administratif di SDN 03 Bejen Karanganyar.

\section{HASIL DAN PEMBAHASAN}

Berdasar hasil penelitian, bentuk program pembiasaan harian maupun 
mingguan yang ada di SD Negeri 03 Bejen Karanganyar antara lain:

\section{Sambut guru dan siswa}

Setiap pagi dimulai pukul 06.30, guru sudah bersiap di depan gerbang sekolah untuk menyambut siswa yang datang ke sekolah. Tak lupa senyum dan salam selalu terucap dari guru maupun siswa sebagai wujud kasih sayang dan kebersamaan. Siswa menjabat dan mencium tangan guru yang menyambut di depan gerbang maupun guru yang baru datang tanpa memandang apakah itu wali kelasnya atau bukan. Siswa juga dibiasakan untuk menyapa tamu yang datang di sekolah.

Karakter yang diharapkan terbentuk dalam diri siswa-siswi adalah hormat dan santun. Hormat adalah bentuk karakter yang membuat seseorang selalu menghargai dan menghormati orang lain. Penghormatan adalah perbuatan untuk takzim, menghargai, menjunjung tinggi, dan memuliakan orang lain (Suwarna, 2014). Sedangkan santun lebih merujuk pada sikap, tata bahasa, dan tata perilaku yang halus. Santun yaitu berperilaku interpersonal sesuai tataran norma dan adat istiadat setempat (Risa Adi, 2019). Selain itu karakter bersahabat dan komunikatif sangat diharapkan terbentuk dengan adanya kegiatan ini. Menurut Zamroni (Akhsan Makhrusan, 2016:23) bersahabat dan komunikatif adalah kemampuan seseorang untuk berbicara, bergaul, dan bekerjasama dengan orang lain dengan rasa senang.

\section{Tadarus pagi}

Kegiatan tadarus pagi sebelum kegiatan belajar mengajar telah terlaksana secara terjadwal dimulai pukul 07.00. Kegiatan tadarus pagi dipimpin secara serentak oleh siswa kelas V dan VI yang mendapat giliran piket secara bergantian melalui speaker yang berpusat di ruang guru dan dihubungkan dengan semua kelas. Dalam pelaksanaannya siswa-siswi sudah bisa mandiri untuk melaksanakan tadarus. Masing-masing siswa sudah siap dengan Al Qur'an maupun Juz Amma yang dibawa maupun yang disediakan di kelas. Untuk kelas I dan II perlu bimbingan yang lebih intensif.

Saat pelaksanaan tadarus, terkadang masih ada siswa yang mengobrol jika tidak diawasi guru. Tetapi, hal itu terjadi hanya terjadi pada sebagian kecil siswa. Untuk mengantisipasi hal tersebut, guru memantau secara berkala sehingga anak-anak dibiasakan untuk tertib. Surat yang dibaca siswa setiap harinya adalah surat-surat pendek dari Jus 30 secara berurutan setiap 15 menit dan akan dilanjutkan keesokan harinya. Siswa yang beragama non Islam dipersilahkan untuk berkumpul di satu ruang membaca kitab sucinya masing-masing.

Karakter yang diharapkan tumbuh dalam diri siswa-siswi adalah religius dan disiplin. Religius adalah sikap dan perilaku yang patuh dalam melaksanakan ajaran agama yang dianutnya.. Sedangkan yang dimaksud dengan disiplin yaitu tindakan yang menunjukkan perilaku tertib dan patuh pada berbagai ketentuan dan peraturan. (Fadhillah, 2013).

\section{Hormat bendera, menyanyikan lagu kebangsaan dan lagu daerah}

Setelah kegiatan tadarus pagi, pada awal jam pertama siswa dibiasakan untuk menyanyikan lagu kebangsaan Indonesia Raya dilanjutkan menyanyikan lagu nasional. Sebelumnya siswa disiapkan terlebih dahulu untuk berdiri dan hormat bendera oleh ketua kelas masing-masing. Kemudian dipimpin oleh Kepala Sekolah atau guru piket melalui speaker utama, siswa menyanyikan lagu Indonesia Raya dan salah satu lagu nasional secara bersama-sama masih dalam posisi 
berdiri. Siswa duduk setelah mendapat abaaba. Setelah jam terakhir, siswa dibiasakan menyanyikan salah satu lagu daerah. Sebelum bernyanyi, ketua kelas terlebih dahulu memberi aba-aba teman-temannya untuk berdiri dan hormat pada bendera dilanjutkan dengan doa di dalam hati.

Karakter yang diharapkan terbentuk dalam diri siswa adalah adalah cinta tanah air dan semangat kebangsaan. Cinta tanah air adalah cara berpikir dan bersikap yang menunjukkan kesetiaan dan penghargaan yang tinggi terhadap bahasa, lingkungan fisik, sosial, budaya, ekonomi, dan politik bangsa. Sedangkan semangat kebangsaan adalah sikap menempatkan kepentingan bangsa dan negara di atas kepentingan pribadi maupun kelompoknya. (Fadhillah, 2013).

\section{Doa bersama sebelum dan sesudah KBM}

Setelah hormat bendera dan menyanyikan lagu nasional, dilanjutkan membaca doa bersama yang dipimpin oleh Kepala Sekolah maupun guru piket. Doa dimulai dari membaca Surat Al Fatihah, doa akan memulai kegiatan belajar beserta artinya. Hal ini dilakukan agar siswa memahami makna dan tujuan dari doa yang diucapkan.

Karakter yang diharapkan terbentuk adalah religius dan toleransi. Toleransi terlihat saat doa bersama, siswa non Islam menghargai siswa yang mayoritas beragama Islam dengan tidak ramai dan mengganggu siswa lain. Menurut Mardiah, toleransi adalah sikap menghargai perbedaan agama, suku, etnis, pendapat, sikap, dan tindakan orang lain yang berbeda dari dirinya. Selain itu sikap bersahabat/komunikatif juga diharapkan dapat terbentuk dalam diri siswa.

\section{Literasi dan kunjung perpustakaan}

Terdapat pojok baca di setiap kelas yang berisi buku-buku bacaan seperti majalah/ tabloid anak, ensiklopedia, buku cerita anak, buku referensi ilmu pengetahuan, dll. Pojok baca digunakan untuk kegiatan literasi setiap pagi sebelum KBM dimulai. Untuk siswa kelas III-VI, masing-masing mempunyai jurnal literasi yang diisi oleh siswa sendiri mengenai telaah buku atau majalah yang dibaca. Jurnal literasi berisi hari dan tanggal, judul buku, halaman yang dibaca, ringkasan bacaan. Bacaan yang belum selesai pada hari itu, dapat dilanjutkan keesokan harinya.

Untuk kegiatan kunjung perpustakaan dilakukan secara kondisional saat jam istirahat. Tetapi ada kegiatan kunjung perpustakaan yang terjadwal. Kunjung perpustakaan yang wajib dilakukan siswa dilakukan setiap 1 minggu sekali saat jam terakhir. Dimulai hari Senin diurutkan dari kelas I, Selasa (kelas II), Rabu (kelas III), Kamis (kelas IV), Jumat (kelas V), dan Sabtu (kelas VI).

Karakter yang ingin dibentuk dari kegiatan literasi dan kunjung perpustakaan ini adalah disiplin dan kejujuran. Disiplin terlihat dari runtutan bacaan siswa dan kejujuran terlihat dari hasil telaah bacaan yang dibuat sendiri merupakan sikap yang menjadikan dirinya seseorang yang dapat baik dalam perkataan, tindakan, dan pekerjaan. (Fadhillah, 2013).

\section{Piket kelas berkelompok}

Setiap pagi sebelum bel masuk berbunyi dan sebelum pulang sekolah, siswa melaksanakan piket kelas secara berkelompok. Tugas piket dibagi sendiri oleh anggota piket. Hal ini dilakukan agar pekerjaan dapat segera selesai dan tidak ada rasa iri dalam pembagian tugas. Tugas piket antara lain menyapu lantai, membersihkan jendela, merapikan buku yang terdapat di pojok kelas, mempersiapkan alat dan media mengajar guru, dsb. Siswa yang tidak 
melaksanakan piket di pagi hari tetap melaksanakan piket di siang hari. Hal ini telah disepakati melalui kontrak belajar kelas.

Karakter yang diharapkan terbentuk dalam diri siswa-siswi adalah adalah peduli lingkungan dan tanggung jawab. Peduli lingkungan adalah sikap dan tindakan yang bertujuan melestarikan lingkungan dengan cara mencegah kerusakannya dan memperbaiki apabila telah terjadi kerusakan lingkungan. Sedangkan tanggungjawab adalah sikap dan perilaku seseorang untuk melaksanakan tugas dan kewajibannya dengan sebaik-baiknya, baik itu terhadap diri sendiri, masyarakat, lingkungan (alam, sosial dan budaya), negara dan Tuhan Yang Maha Esa (Fadhillah, 2013).

\section{Sholat dzuhur berjama'ah}

Shalat dzuhur berjama'ah dilaksanakan setiap hari Senin s.d. Kamis sesuai jadwal. Hal ini dikarenakan tempat sholat yang digunakan terbatas. Pengalihan fungsi perpustakaan menjadi mushola sementara membuat tempat yang digunakan untuk sholat tidak dapat digunakan oleh 4 kelas secara bersamaan.Kelas yang mengikuti kegiatan shalat dzuhur berjama'ah adalah kelas III, IV, V, dan VI. Kelas III berjama'ah dengan kelas V setiap hari Senin dan Rabu, sedangkan kelas IV berjama'ah dengan kelas VI setiap hari Selasa dan Kamis. Tetapi terkadang ada siswa yang ikut shalat meskipun bukan jadwalnya. Hal ini terjadi karena adzan berkumandang sesaat sebelum bel masuk berbunyi, sehingga waktu luang sambil menunggu guru masuk ke kelas dimanfaatkan oleh siswa untuk shalat dzuhur berjamaah. Imam shalat adalah Bapak Kepala Sekolah atau bapak guru yang ditunjuk sesuai jadwal. Ada kalanya siswa yang telah akil baligh dan fasih dalam bacaan Al Qur'an ditunjuk untuk menjadi imam.
Adapun karakter yang diharapkan terbentuk dalam diri siswa-siswi adalah religius dan tanggung jawab.

\section{Jumat bersih dan Jumat sehat}

Setiap hari Jumat diadakan kegiatan senam bersama yang dipimpin oleh guru olahraga dimulai pukul 07.15. Siswa kelas VI yang sudah dilatih sebelumnya ikut membantu guru olahraga memberi contoh senam di depan adik-adik kelasnya di beberapa titik. Setelah kegiatan senam dilanjutkan kebersihan dengan cara memungut sampah yang ada di sekitar tempat siswa berdiri dan memasukkannya ke tempat sampah sebelum mereka masuk kelas. Setiap 1 bulan sekali pada hari Jumat, diadakan kerja bakti secara menyeluruh meliputi kebersihan kelas, halaman sekolah, kebun sekolah, selokan, kamar mandi, perpustakaan, mushola, dan jalan sekitar sekolah.

Karakter yang diharapkan terbentuk dalam diri siswa-siswi adalah peduli lingkungan dan tanggung jawab. Infaq Jumat dan Infaq mingguan

Kegiatan infaq dilakukan dua kali dalam seminggu, yakni infaq setiap hari Jumat dan infaq saat jam pelajaran agama. Infaq Jum'at dikumpulkan oleh guru agama setelah pelaksanaan senam bersama. Tidak hanya siswa yang berinfaq, tetapi guru juga berinfaq sebagai contoh terhadap siswa. Dana infaq Jum'at yang terkumpul digunakan untuk membeli hewan kurban (kambing) saat hari raya Idul Adha. Hewan kurban disembelih, dimasak, dan dimakan bersama-sama guru dan semua siswa. Hal ini dilakukan untuk melatih siswa berkurban.

$$
\text { Sedangkan infaq mingguan }
$$
dikumpulkan oleh petugas yang ditunjuk, dicatat, dan diserahkan ke guru agama. Dana infaq mingguan digunakan untuk kegiatan sosial antara lain takziah keluarga guru 
maupun siswa, menjenguk siswa yang sakit, membantu siswa yang tidak mampu ikut kegiatan yang diharuskan membayar. Kegiatan ini dilakukan agar siswa terbiasa menyisihkan sebagian uang sakunya secara sukarela untuk teman yang membutuhkan.

Karakter yang ingin dikembangkan dengan kegiatan ini adalah toleransi, dimana siswa selalu menghargai orang lain tanpa melihat perbedaan. Selain itu karakter kasih sayang, peduli sosial,dan kerjasama juga diharapkan dapat tertanam pada diri siswa. Menurut Zamroni (Akhsan Makhrusan, 2016:23), peduli sosial adalah sikap dan tindakan yang selalu ingin memberi bantuan bagi orang lain dan masyarakat yang membutuhkan.

Program pembiasaan yang dilaksanakan di SD Negeri 03 Bejen berjalan sesuai dengan program yang telah dibuat dan berjalan sesuai dengan yang diharapkan. Sebagian besar kegiatan pembiasaan dilakukan secara terjadwal. Meskipun ada yang dilakukan secara kondisional seperti kunjung perpustakaan saat istirahat. Dikatakan secara kondisional karena tidak ada jadwal wajib yang harus dipatuhi siswa untuk melakukannya. Ada anak yang berkunjung ke perpustakaan saat istirahat dan ada yang tidak. Anak-anak juga dibiasakan membuang sampah di tempat sampah, menyapa guru maupun tamu yang datang di sekolah, mengucapkan salam ketika masuk kelas, selalu berpakaian rapi dan memakai atribut seragam yang lengkap.

Kegiatan pembiasaan yang dilaksanakan di SDN 03 Bejen dapat dikategorikan menjadi 4 bentuk, yakni pembiasaan terprogram, pembiasaan rutin, pembiasaan spontan dan pembiasaan keteladanan. Hal ini dibuktikan dengan adanya kegiatan sambut guru dan siswa. Guru memberi contoh pada siswa untuk menyambut setiap teman yang datang dengan senyum dan sapa. Kegiatan senam bersama, Ju'mat bersih dan infaq juga dilakukan oleh guru sebagai wujud keteladanan.

Program pembiasaan di SD Negeri 03 Bejen bertujuan untuk memodifikasi tingkah laku siswa dari yang sebelumnya kurang baik menjadi lebih baik. Modifikasi perilaku atau disebut behavioris secara umum dapat didefinisikan sebagai segala tindakan yang bertujuan mengubah perilaku. Oleh karena itu program pembiasaan di SD Negeri 03 Bejen mengarahkan siswa untuk mempelajari dan menyukai tingkah laku yang baik. Siswa yang sebelumnya memiliki perilaku menyimpang, akan merasa bersalah dalam dirinya karena lingkungan tidak mendukung dirinya untuk berbuat tidak baik.

\section{KESIMPULAN}

Program pembiasaan di SD Negeri 03 Bejen yang dilaksanakan secara terjadwal antara lain (a) Sambut guru dan siswa, (b) Tadarus pagi, (c) Hormat bendera, menyanyikan lagu kebangsaan dan lagu daerah, (d) Doa bersama sebelum dan sesudah KBM, (e) Literasi dan kunjung perpustakaan, (f) Piket kelas berkelompok, (g) Sholat dzuhur berjama'ah, (h) Jumat bersih dan Jumat sehat, dan (i) Infaq Jumat dan Infaq mingguan. Untuk pembiasaan secara kondisional maupun spontan antara lain kunjung perpustakaan, membuang sampah di tempat sampah, menyapa guru maupun tamu sekolah, mengucapkan salam ketika masuk kelas, dan selalu berpakaian rapi dan memakai atribut seragam yang lengkap.

Kegiatan pembiasaan yang dilakukan sekolah dapat menumbuhkan sikap peserta didik yang lebih baik. Sikap peserta didik yang belum baik menjadi baik. Sikap yang belum tampak karakternya menjadi tampak 
dan tumbuh dengan baik. Sikap-sikap inilah yang menjadikan peserta didik memiliki karakter yang baik. Karakter yang terbentuk yaitu religius, disiplin, bertanggung jawab,toleransi, hormat dan santun, cinta tanah air, semangat kebangsaan, jujur, peduli lingkungan maupun sosial.

Keberhasilan pembentukan karakter melalui pembiasaan sangat didukung oleh partisipasi semua warga sekolah. Kepala sekolah, guru, dan staf di sekolah harus bisa menjadi teladan yang baik bagi siswa. Karena tugas utama pengajar tidak hanya mengajarkan ilmu ( transfer of knowledge) tetapi juga mengajarkan nilai-nilai kehidupan (transfer of value).

\section{DAFTAR RUJUKAN}

Ahsan Masrukhan. (2016). Pelaksanaan Pendidikan Karakter Peduli Sosial di SD Negeri Kotagede 5 Yogyakarta. Skripsi. Fakultas Ilmu Pendidikan. Universitas Negeri Yogyakarta: Yogyakarta.

Al-Abrasyi, Muhammad 'Athiyah. (1974). Dasar-Dasar Pokok Pendidikan Islam, terj. Bustami A. Gani dan Djohar Bahry L.I.S. Jakarta: Bulan Bintang.

Efa Widyastuti. (2016). Penanaman Pendidikan Karakter Melalui Pembiasaan di SD Al-Azhar Syifa Budi Surakarta. Pasca Sarjana Administrasi Pendidikan.

Universitas Muhammadiyah Surakarta. Diakses dari http://eprints.ums.ac.id.

Fadhillah, Muhammad dan Lilif Mualifatu Khorida. (2013). Pendidikan Karakter Anak Usia Dini. Yogyakarta: Ar-Ruzz Media.

Laila, Qumruin Nurul. (2015). Pemikiran Pendidikan Moral Albert Bandura. Vol.III, NO.1, Maret. Akses 10 Juni 2021.
Mardiah, Baginda. Nilai-nilai Pendidikan Berbasis Karakter pada Pendidikan Dasar dan Menengah. https://media.neliti.com. Akses 20 Juni 2021.

Mulyasa, E. (2013). Manajemen Pendidikan Karakter. Jakarta: Bumi Aksara.

Novia Elva S. (2019). Upaya Pendidikan Karakter Siswa Melalui Metode Pembiasaan Di SMAN 2 Ponorogo. Skripsi. Fakultas Tarbiyah dan Ilmu Keguruan. Institut Agama Islam: Ponorogo.

Risa Adi S. (2019). Pembentukan Karakter Sopan Santun Melalui Pembiasaan Berbahasa Jawa Krama di MI Nashrul Fajar Meteseh Tembalang. Skripsi. Tidak Diterbitkan. Fakultas Ilmu Tarbiyah Dan Keguruan. Universitas Islam Negeri Walisongo: Semarang.

Samrin. (2016). Pendidikan Karakter, Sebuah Pendekatan Nilai. Jurnal AlTa'dib, Vol. 9 No.1.Januari-Juni. Akses 10 Juni 2021.

Sugiyono. (2007). Metode Penelitian Pendidikan. Bandung. Jakarta Alfabeta. Suwarna dan Suharti. (2014). Pendidikan Karakter Hormat dalam Buku Pelajaran Bahasa Jawa di Sekolah. Jurnal Pendidikan Karakter, Tahun IV Nomor 2, Juni. Akses 26 Juni 2021.

Syah, Muhibbin. (1995). Psikologi Pendidikan: Suatu Pendekatan Baru, Bandung: PT. Remaja Rosdakarya.

Tresnani, Lia Dwi. (2020). Program Pembiasaan Harian dalam Membentuk Karakter Siswa Ditinjau dari Perspektif Psikologi Belajar. ISTIGHNA, Vol. 3, No 1, Januari. http://e-journal.stit-islamicvillage.ac.id/index.php/istighna. Akses 10 Juni 2021. 